\title{
Identifikasi dan Inventarisasi Permasalahan Pelestarian Situs Makam Megalitikum di Distrik Mulyosari, Kecamatan Malangsari, Kabupaten Banyuwangi, Jawa Timur
}

\author{
Uji Nugroho Winardi, Agus Suwignyo, Baha'Uddin, Sri Margana \\ Departemen Sejarah, Fakultas Ilmu Budaya, Universitas Gadjah Mada
}

Tim pengabdian kepada masyarakat:

Uji Nugroho Winardi, Agus Suwignyo, Baha'Uddin, Sri Margana

\begin{abstract}
Abstrak
Keberadaan situs makam purba di Banyuwangi menyimpan potensi data sejarah untuk menguak asal-usul peradaban masyarakat Jawa. Namun, makam-makam itu telah mengalami perusakan akibat aktivitas penjarahan benda-benda kubur dalam kira-kira lima belas tahun terakhir. Kegiatan Pengabdian kepada Masyarakat ini bertujuan mengidentifikasi persoalan-persoalan sosial-ekonomi dan substansi objek kajian situs untuk menghentikan penjarahan dan mengangkat potensi makam purba, baik secara akademis dan politis menyangkut kebijakan pengelolaan warisan sejarah, maupun secara sosial-ekonomi bagi masyarakat setempat. Kegiatan Pengabdian kepada Masyarakat dilakukan pada November 2015. Tim menemukan bahwa penjarahan situs makam oleh penduduk dilatarbelakangi persoalan ekonomi. Meskipun demikian, jaringan persoalan berakar pada aspek politik yaitu ketiadaan kebijakan yang menempatkan areal makam situs purba sebagai daerah cagar budaya. Persoalan ini sangat berkaitan dengan rendahnya tingkat kesadaran pemerintah dan warga. Selain itu, ada persoalan kompleks menyangkut kepemilikan dan pengelolaan lahan areal situs makam, yang merupakan perkebunan kopi.
\end{abstract}

Kata kunci: Situs makam purba, identifikasi, cagar budaya, Banyuwangi

\begin{abstract}
The existence of ancient grave sites in Banyuwangi save the potential of historical data to uncover the origins of Javanese civilization. However, the sites have been damaged by the activity of looting graves in the last fifteen years. This Community Engagement Activity aims to identify socio-economic issues and the substance of the object of the site study to stop looting and raise the potential of ancient tombs academically and politically concerning historical heritage management policies, as well as socioeconomically for the local community. Community Engagement Activities was conducted in November 2015. The team found that the looting of grave sites by residents was motivated by economic problems. Nevertheless, the problem network is rooted in the political aspect of the absence of a policy that places the ancient site's grave as an area of cultural heritage. This issue is closely related to the low level of awareness of government and citizens. In addition, there are complex issues concerning the ownership and management of the land area of the grave site, which is a coffee plantation.
\end{abstract}

Keywords: Ancient grave sites, identification, cultural preservation, Banyuwangi 


\section{Pengantar}

Dalam sekitar lima belas tahun ini terjadi pencurian massif benda-benda purbakala oleh masayarakat lokal dan para "pemburu harta karun". di daerah Patung Rejo, Manikan (Kabupaten Jember) ke timur; daerah Pesanggrahan, Pringgondani kawasan Gunung Sanen (batas Kabupaten Banyuwangi dan Kabupaten Jember), tepatnya selatan Gunung Kumitir daerah Malangsari-Mulyosari dan Margosari-Kendanglembu, Terbasalak, situs Trucuk kalibening dusun Pagondangan, situs Gunung Keraton, Kecamatan Glenmore, wilayah aliran Sungai Lele, daerah Karangharjo Blokagung, Kecamatan Tegalsari sampai ke Desa Seneporejo wilayah Kecamatan Pesanggaran. Daerah-daerah tersebut menyimpan potensi kekayaan peradaban megalitikum. Artefak yang ditemukan berupa tembikar, gerabah, sejumlah fragmen beliung, beliung setengah jadi, batu asahan yang berfaset dan sejumlah pecahan batu diperkirakan berfungsi sebagai alat-alat produksi pertanian. Di atas temuan yang lebih muda diketemukan beberapa pecahan porselin, beberapa uang kepeng, pecahan bata dan sejumlah kereweng tak berhias, yang semuanya diperkirakan berasal dari masa pra-sejarah. Temuan lain dari riset di daerah Kandanglembu oleh Soejono (1969) adalah sebaran batu kubur yang mengindikasikan adanya kebudayaan tua di masa lalu.

Perusakan oleh para pemburu harta karun dan pencurian yang kebanyakan berlatar belakang persoalan ekonomi ini tidak memperoleh respon dari pihak berwajib. Di sisi lain, para pemodal dari luar siap menampung hasil jarahan benda-benda purbakala. Jika kondisi ini dibiarkan berlanjut tanpa ada langkah-langkah penyelamatan konkrit, dapat dipastikan jejak peradaban megalitikum yang sangat berarti itu hilang. Kegiatan Pengabdian kepada Masyarakat ini bertujuan untuk mendampingi masyarakat dan pengelola perkebunan di areal makam magalitikum untuk meningkatkan kesadaran tentang pentingnya menjaga situs warisan budaya di tempat itu. Kegiatan pendampingan juga melibatkan komunitas lokal pemerhati dan pecinta warisan budaya.

Afdeeling Mulyosari, Distrik Malangsari, yang menjadi lokus kegiatan ini, terletak sekitar 23 km dari kota Kecamatan Kalibaru, Banyuwangi. Desa ini berada paling ujung dari deretan pemukiman-perkebunan warisan kolonial di perbatasan Gunung Meru Betiri dan Gunung Kendhil. Saat ini perkebunan dimiliki oleh perkebunan kopi PTPN XII Nusantara. Orang-orang yang berdiam di Mulyosari berasal dari Madura. Para buruh ini bertempat tinggal jauh dari fasilitas kesehatan dan pendidikan, dan tidak memiliki sumber-sumber ekonomi yang berkelanjutan. Kebanyakan dari mereka mengandalkan hidup dari upah yang diterima dari bekerja di kebun milik PTPN. Ada kasus dalam satu keluarga terdapat ibu, bapak dan anak yang bekerja sebagai buruh dengan upah sebesar Rp 27.000,- per orang setiap hari.

Pada dekade 1990an, terjadi penjarahan kayu dari hutan Perhutani. Setelah hutan menyempit, banyak orang di Mulyosari melakukan penggalian untuk menemukan harta karun sebagaimana terjadi di Jember. Sejumlah penggali berhasil menemukan sorkofagus yang berisi bekal kubur berupa arca batu, senjata, tombak, manik-manik dan perhiasan emas. Sejak itu semakin banyak perburuan dilakukan. Penjarahan dan pengrusakan massal meluas ke daerah perkebunan Malangsari, Mulyosari, Margosari dan wilayah petak 1A dan 1B milik Perhutani Banyuwangi Selatan. Pada tahun 1996, terjadi penjarahan dan pengerusakan massal terhadap situs Trucuk di Kalibening Pagondangan 
Kecamatan Glenmore. Dari hasil wawancara terhadap penduduk, artefak megalitikum sebanyak sekitar 19 truk dijual ke Bali, 1 truk tertangkap polisi di Ketapang.

Di Mulyosari sendiri terdapat tingkat sebaran situs, terutama kubur batu, yang sangat rapat. Dari hasil penelusuran terhadap bekas galian yang ditinggalkan para pemburu harta karun, pada areal tertentu bisa didapati satu kubur batu berdampingan sekitar 1 meter dengan kubur batu yang lain. Berdasarkan pengakuan beberapa penggali dan pengamatan langsung, hasil temuan artefak megalitik yang ada disana berupa Sarkofagus, dolmen, menhir, batu lesung, rumah batu, batu lesung, batu kenong, arca batu, manik-manik, golok, tombak, cincin emas berbentuk naga, cincin emas yang melekat di hidung, kubur tempayan dan beberapa kerangka tengkorak dengan berbagai ukuran besar dan kecil. Bahkan pernah ditemukan kotak peti mayat yang dibalsem.

Adapun jangkauan kerusakan yang diakibatkan oleh adanya aktifitas perburuan harta karun ini bervariasi. Di wilayah ini, artefak tersebar di tiga areal—berdasar status peguasaan tanah—yakni Perhutani, PTPN dan HGO warga. Areal PTPN XII Afdeling Mulyosari seluas 652 ha paling parah dari aktivitas penggalian liar untuk mengambil manik-manik dan perhiasan emas. Hal ini sangat dimungkinkan karena sebaran kubur batu dibumbui cerita sukses temuan-temuan bernilai ekonomis. Luas lahan juga tidak dapat dipatroli oleh keamanan kebun secara intensif.

Sementara itu, areal milik Perhutani wilayah petak 1B daerah Sumber Lutung dengan luas 2800 hektar. Lebih dari 3000 batu kubur digali dan dijarah. Pada petak 1A yang berstatus hutan lindung dengan luas 3000 ha juga dijarah, namun tingkat kerusakannya tidak separah areal kebun PTPN.

\section{Desain Program dan Metode}

Program Pengabdian kepada Masyarakat ini didesain sebagai usaha sinergi warga akademik kampus dengan masyarakat lokal untuk melakukan penyelamatan benda-benda peninggalan sejarah yang ada di afdeeling Mulyosari distrik Malangsari Banyuwangi, Jawa Timur. Salah satu usaha penting dari proyek ini ialah mengurai kompleksitas persoalan menyangkut benda-benda cagar budaya yang rawan pencurian-penjarahan. Upaya ditempuh dengan jalan pelibatan dari dalam, yakni melalui partisipasi warga.

Mengingat kompleksitas yang ada di Mulyosari, pelestarian situs-situs hanya akan dapat dilakukan jika basisnya adalah keterlibatan warga masyarakat setempat. Oleh karena itu diperlukan semacam rekayasa sosial untuk melibatkan dan mendorong partisipasi warga sebagai garda terdepan penjaga peninggalan bersejarah di Mulyosari. Sejauh ini, tim pengabdian telah berjejaring dengan komunitas lokal maupun individu yang memiliki perhatian dengan isu pelestarian benda-benda warisan sejarah.

Langkah selanjutnya meliputi:

1. Melakukan edukasi melalui partisipasi warga akan arti pentingnya situs-situs bersejarah di Mulyosari dan sosialisi undang-undang cagar budaya.

2. Membentuk kelompok-kelompok "sadar warisan budaya" berbasis warga lokal.

3. Menjembatani para-pihak yang memungkinkan pelestarian situs sejarah berbasis warga dengan mengakomodasi faktor sosial dan kepentingan ekonomi.

4. Mendorong dilakukannya riset ilmiah terhadap situs di Mulyosari dengan menekankan pada pelibatan masyarakat lokal. 
Metode kegiatan ini mencakup: identifikasi dan pemetaan permasalah yang ditempuh dengan cara survei ke lapangan dan melakukan wawancara dengan penduduk setempat, pengelola Perkebunan PTP XII, dan melalui focus group discussion dengan kelompokkelompok lokal pecinta warisan budaya. Setelah identifikasi dan pemetaan, kegiatan selanjutnya adalah menelusuri situs-situs megalitikum secara keseluruhan. Dalam proses ini, juga dilakukan pemetaan tentang areal yang telah mengalami penjarahan. Tahap selanjutnya merupakan pengolahan hasil kedua langkah itu melalui diskusi partisipatif dengan pengelola afdeeling perkebunan dan sejumlah penduduk.
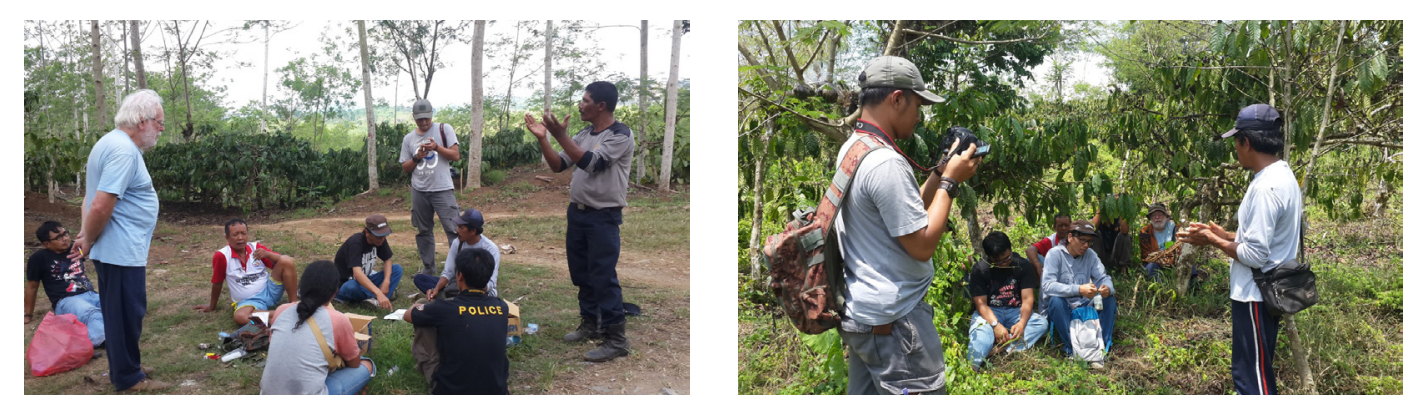

Foto 1 dan 2. Survei lapangan, interview kepada para warga serta pegawai perkebunan, sekaligus melakukan pemetaan areal yang mengalami kerusakan akibat penjarahan

\section{Kehidupan Masyarakat Perkebunan}

\section{Deskripsi Umum}

Mulyosari merupakan salah satu afdeeling dalam distrik Malangsari dan secara administratif merupakan bagian dari desa Kebonrejo kecamatan Kalibaru kabupaten Banyuwangi. Afdeeling ini terletak pada ketinggian 595 dpl. Jarak tempuhnya sekitar 2 jam dari stasiun Kalibaru menggunakan mobil. Malangsari merupakan wilayah perkebunan yang menjadi bagian dari PTPN XII. Nama Malangsari berasal dari MalangSingosari. Meskipun berstatus sebagai bagian dari desa namun distrik Malangsari dan afdeeling Mulyosari lebih tepat dikatakan sebagai enclave pekerja kebun. Penduduk tidak mengenal siapa lurah, dukuh atau carik mereka. Yang mereka ketahui adalah sinder, mandor, keamanan dan manager kebun.

Kebun Malangsari memiliki komoditas utama tanaman kopi robusta dan tanaman pendukung lain seperti kakao, tebu dan sengon-laut. Kebun utama PTPN XII di Malangsari berhimpit dengan perkebunan rakyat. Kebun-kebun dihuni oleh pohon yang terlihat sudah telah kepayahan dan seolah enggan berbuah. Hal ini mengilustrasikan laju dinamika sosial dan relasi kerja yang ada di Mulyosari.

\section{Cara bertahan bidup penduduk}

Para buruh perkebunan bekerja sekitar enam jam setiap hari dari pukul 07.00 sampai 13.00. Meskipun mulai bekerja terhitung pukul 07.00, selepas subuh mereka telah mulai mempersiapkan diri.Dikenal dua jenis buruh yakni buruh lepas dan buruh kontrak. 
Buruh lepas ini berasal dari berbagai tempat di sekitar Banyuwangi dan Jember. Pada saat musim panen jumlah buruh lepas yang direkrut perusahaan dapat mencapai ribuan orang pekerja. Adapun buruh kontrak tinggal di afdeeling-afdeeling sekitar perkebunan dengan menempati tanah dan rumah yang dipinjamkan oleh perusahaan. Sehari-hari pekerja ini adalah merawat kebun kopi dan ditambah kegiatan lain seperti menanam sengon, membuat kolom dan aktifitas lainnya yang diagendakan oleh perkebunan.

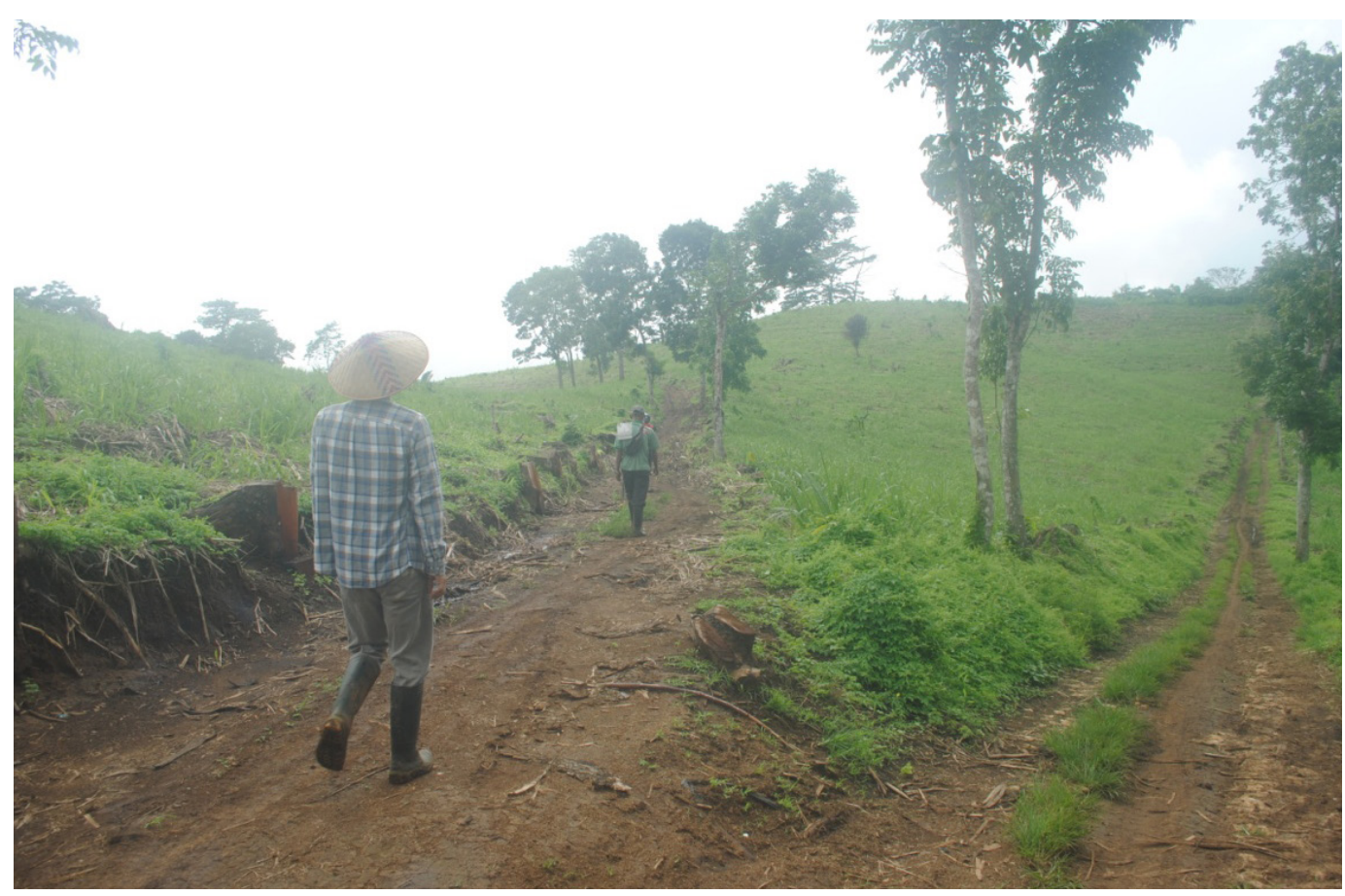

Foto 3. Jalan yang biasa dilalui warga untuk menuju kebun kopi, ladang penduduk, dan lahan perhutani.

Kehidupan di afdeeling perkebunan memiliki nuanasa seperti sebuah frontier. Jauh dari pusat kota, administrasi dan jauh pula berbagai akses dan fasilitas. Status mereka sebagai buruh kontrak juga tidak begitu menguntungkan seara ekonomi. Meskipun mereka berstatus sebagai pekerja kontrak namun aktifitas kebun yang didasarkan pada anggaran, menjadikan mereka sebenarnya hanya bekerja — sehingga memperoleh upahpada musim-musim tertentu saja. Namun antara para buruh dengan perusahaan ada keterikatan yang lebih didasarkan pada kebutuhan untuk memperoleh "ruang" ekonomi. Paling tidak, "ruang ekonomi" ini dapat berupa dua hal: pekerjaan serta tempat tinggal; dan akses terhadap sumber produksi berupa tanah.

Sejak geger penggundulan hutan di akhir dekade 1990, pemerintah dan perhutani mengambil solusi dengan mengijinkan pengelolaan lahan dilakukan oleh masyarakat untuk menghijaukan kembali hutan yang rusak. Para buruh, selain bekerja di perusahaan, juga memiliki pekerjaan lain yakni bertani atau berkebun di tanah yang mereka kelola. Lebih dari sekedar pekerjaan sampingan, bertani dan berkebun di lahan sendiri jauh lebih menguntungkan, terutama bagi mereka yang menggarap tanah dalam skala lebih dari satu hektar. 


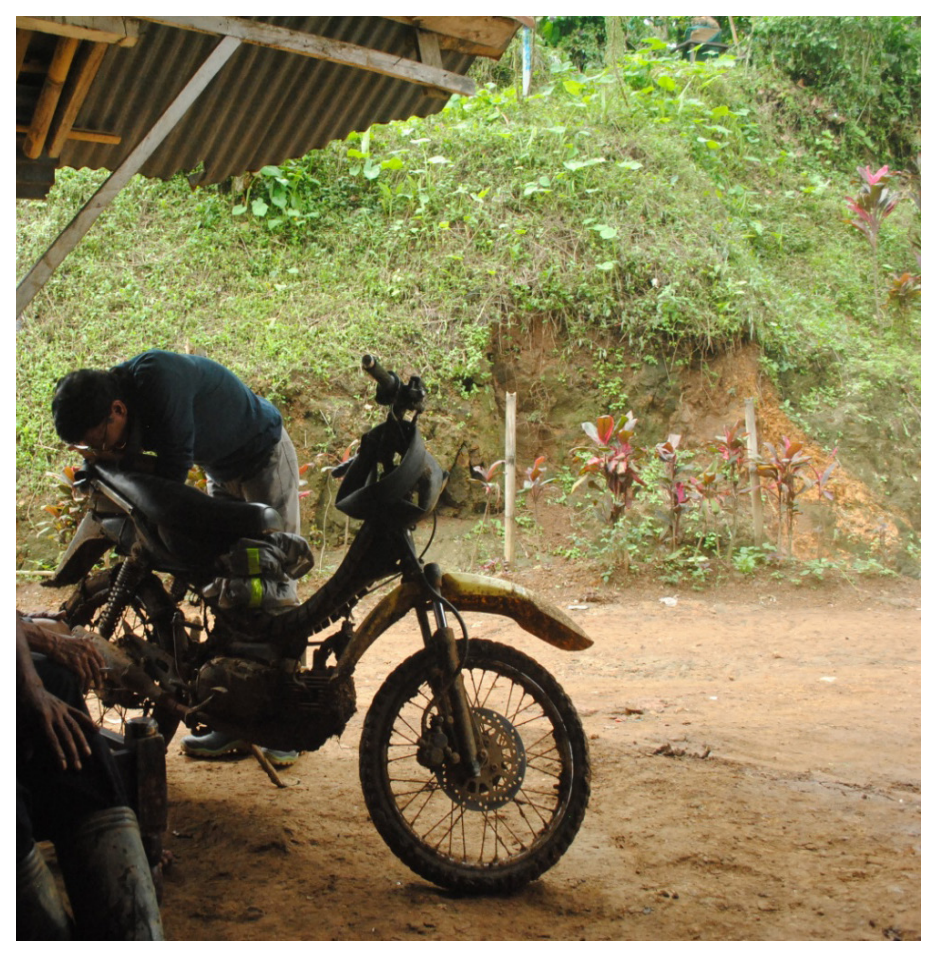

Foto 4. Kendaraan penduduk harus dimodifikasi dengan menambahkan rantai agar dapat dipergunakan pada jalan berlumpur.

Pada tahun 2014 nilai panen kopi satu tahun yang dihasilkan kebun dengan luas satu hektar mencapai 50 juta, bersih. Penduduk sering mengistilahkannya dengan uang tabungan. Adapun kopi butuh tanaman perindang, dan dalam kebun kopi dapat ditanami berbagai macam tanaman buah alpokat, durian, dan rambutan. Semuanya memiliki nilai ekonomis. Sekali panen, alpokat misalkan, dapat dijual dengan sistem tebas senilai Rp. 800.000 sampai satu juta rupiah. Durian akan lebih mahal lagi, tergantung kualitas panen. Hasil penjualan ini dapat disebut uang musiman yang kadang lebih sering di-ijon-kan. Adapun sejumlah penduduk juga mengembangkan ternak berupa ayam dan kambing. Kandang kambing dengan ukuran besar ditaruh di ladang, dapat menampung hingga duapuluhan ekor. Untuk kebutuhan mendesak, misalkan biaya berobat ataupun sekolah anak, kambing dapat dijual.

Untuk biaya hidup di Mulyosari dapat disebut murah sekali. Sejumlah informan mengatakan bahwa uang perbulan yang dihabiskan tidak lebih dari biaya beli beras dan garam. Pengeluaran terbesar penduduk adalah untuk rokok. Sejumlah orang menginvestasikan uang yang mereka peroleh dari hidup di kebun dalam bentuk properti di kota terutama di Kalibaru, biasanya berupa kios atau rumah untuk disewakan.

Cerita di atas adalah beberapa contoh sukses. Namun tidak semuanya beruntung. Ada penduduk yang terlilit hutang, atau tidak dapat memperoleh akses terhadap sumber produksi. Kelompok ini umumnya memiliki ketergantungan sangat tinggi terhadap perkebunan. Beberapa di antaranya juga melakukan pekerjaan lain untuk menambah penghasilan, termasuk jual beli hasil penggalian harta karun. 


\section{Persebaran Situs Megalithikum di Banyuwangi}

Peninggalan budaya megalitihik di wilayah Jawa Timur bagian timur tersebar terutama di tiga kabupaten yaitu di Jember, Bondowoso, dan Banyuwangi. Dalam kajian arkeologi peninggalan budaya megalitihik di wilayah ini disebut dengan istilah kelompok budaya megalit Besuki. Hal tersebut merujuk pada sebaran peninggalan budaya megalitihik yang pada umumnya berada di wilayah bekas Karesidenan Besuki. Dari ketiga wilayah itu, peninggalan benda-benda megalithikum dalam jumlah yang paling besar ada di Bondowoso yang diperkirakan sebagai pusat peradaban budaya megalithik di wilayah Jawa Timur bagian timur. Di wilayah Jember, peninggalan benda-benda megalithik ditemukan di Situs Duplang yang terletak di Desa Kamal, Kecamatan Arjasa, Kabupaten Jember. Benda-benda purbakala di wilayah Situs Duplang banyak ditemukan di areal persawahan dan perkebunan.
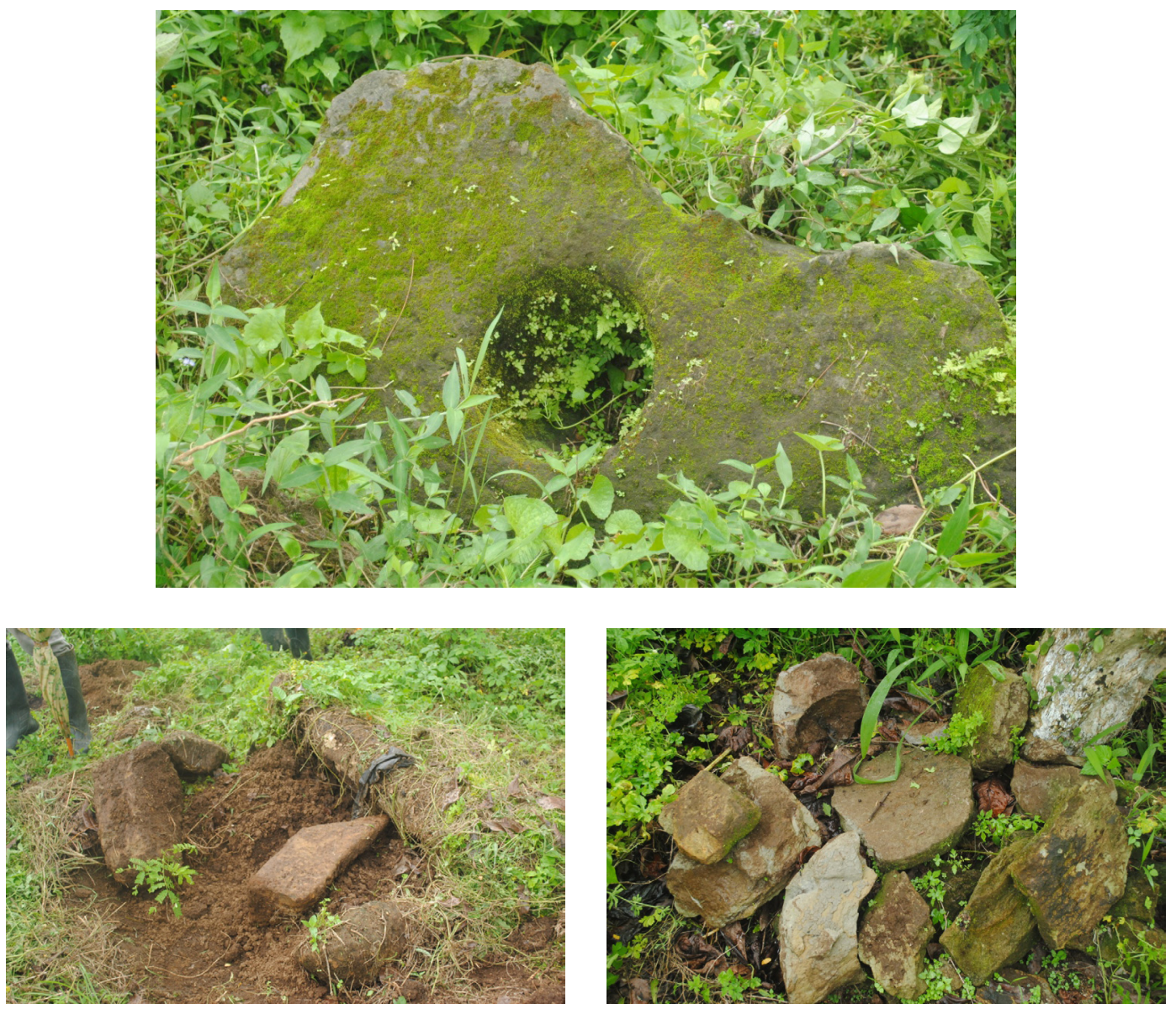

Foto 5, 6, dan 7. Sebaran tinggalan masa megalitikum di Bondowoso

Di wilayah Bondowoso ditemukan hampir semua jenis benda masa megalithikum. Berbagai peninggalan budaya megalitik yang ditemukan di Bondowoso antara lain sarkofagus (pandhusa), dolmen, kubur kamar batu, teras berundak, menhir, arca, maupun batu kenong. Pada masanya, tinggalan-tinggalan ini berfungsi sebagai sarana penguburan 
maupun pemujaan. Sebagai sarana penguburan, yaitu sebagai wadah kubur berupa Sarkofagus, Dolmen, dan Kubur Kamar Batu, sedang sebagai sarana pemujaan adalah Teras Berundak, Menhir, dan arca. Sementara itu fungsi Batu Kenong sampai sekarang masih diperdebatkan. Fungsi teknis sebagai umpak landasan tiang suatu bangunan, tampaknya fungsi Batu Kenong tersebut lebih banyak diyakini oleh para ahli dari pada berfungsi lain, misalnya sebagai media pemujaan.

Benda-benda bersejarah itu tersebar di lima desa dan kecamatan, yakni di Desa Pakauman (Kecamatan Grujugan), Desa Mas Kuning Lor (Kecamatan Pujer), Desa Pakisan (Kecamatan Wonosari), dan Desa Glingseran (Kecamatan Wringin). Dari hasil penelitian para arkeolog, ditemukan 15 buah Sarkopagus di Kecamatan Grujugan. Selain Sarkopagus, ditemukan pula Dolmen (15), Batu Kenong (65), dan sebuah patung nenek moyang. Di Pujer juga ditemukan peninggalan tradisi megalitik berupa 80 buah Dolmen, Batu Kenong (12), dan lima buah alat rumah tangga. Di Kecamatan Tlogosari ditemukan lima buha Yoni, Relief (1), Sarkopagus (10), Dolmen (4), Batu Kenong (15), dan sebuah alat rumah tangga. Sementara Kecamatan Wonosari hanya menyimpan 30 buah Dolmen, Kecamatan Wringin menyimpan 67 buah Sarkopagus, Menhir (1), Batu Kenong (15), alat rumah tangga (10), dan dua gua alam.

Sementara itu di wilayah Banyuwangi juga terdapat benda-benda peninggalan masa megalithikum. Hampir semua benda-benda peninggalan megalithikum yang ditemukan di wilayah Jember dan Bondowoso juga ditemukan di wilayah Banyuwangi hanya terdapat perbedaan dalam kuantitasnya. Di wilayah ini peninggalan megalithikum tersebar di 2 kecamatan yaitu di Kecamatan Glenmore dan Kecamatan Kalibaru. Di Glenmore pusat peradaban megalithikum terpusat pada situs Kendenglembu sedangkan di Kalibaru terpusat pada sepanjang aliran sungai Kalibaru. Seperti situs yang ditemukan di Jember dan Bondowoso, situs-situs yang ada di Banyuwangi ini juga diperkirakan merupakan situs koloni awal Austronesia di Pulau Jawa, sebagai cikal bakal atau nenek moyang etnis Jawa di pulau ini.

Baik di Situs Kendenglembu maupun di Kalibaru sebagian besar wilayahnya sekarang merupakan wilayah perkebunan PTPN XII. Perkebunan Kendenglembu mula-mula dibuka oleh Belanda dengan nama Landbouw Maatschappij Onderneming David Bernie (LMOD). Pada akhir 1957, perkebunan ini dinasionalisasi atau diambil alih oleh Pemerintah Republik Indonesia dengan nama PPN (Perusahaan Perusahaan Negara). Sejak itu, berkali-kali ganti nama menjadi PPN Kesatuan Jatim VII (1961), PPN Karet XVI (1963), PN XXVI (1968), PT Perkebunan XXVI (1971), Perkebunan Grup Jatim (1994). Dua tahun kemudian, pada 1996, menjadi PT Perkebunan Nusantara XII (Persero) hingga sekarang. Sementara untuk situs di Kalibaru merupakan sebagian masuk wilayah Perkebunan Kopi Malangsari, PTPN XII sebagian lainnya masuk dalam wilayah kawasan hutan lindung Meru Betiri.

Situs Kendenglembu terletak di tengah perkebunan karet di Desa Karangharjo, di bagian selatan Kecamatan Glenmore, diantara Jember and Banyuwangi. Berdasarkan penelitian arkelogi yang pernah dilakukan di situs ini, dapat diketahui bahwa di Situs Kendenglembu terdapat dua lapisan budaya, yaitu lapisan "sejarah" untuk lapisan atas dan lapisan "neolitik" untuk lapisan di bawahnya. Namun demikian, interpretasi mengenai kronologi hunian situs tersebut belum didukung oleh pertanggalan absolut. Pada lapisan "sejarah" ditemukan mata uang kepeng, pecahan gerabah, fragmen bata, 
dan fragmen porcelain. Lapisan "neolitik" menghasilkan beberapa beliung persegi, sejumlah calon beliung, batu pukul, batu asah dan batu giling, batu pelandas, sejumlah tatal dan serpih, beberapa alat serpih dan bilah, serta pecahan tembikar poles merah. Di wilayah Glenmore ini benda-benda peninggalan megalithikum banyak ditemukan di Situs Sukobumi (Afdeling Pegundangan) dan Situs Kendenglembu (Afdeling Besaran) di wilayah perkebunan karet PTPN XII Kendenglembu dan Kalirejo.

Situs Kendenglembu ini tidak berdiri sendiri karena berlanjut ke situs Kalibaru yang ada di wilayah kecamatan Kalibaru terutama yang berada disepanjang aliran Sungai Kalibaru dan diduga hingga ke muara sungai yang masuk ke wilayah Kecamatan Siliragung. Menurut penelitian Balai Arkeologi Yogyakarta pada 2008, di wilayah Banyuwangi selatan ini terdapat 2 zona „pemukiman“ Austronesia yang berbeda, yaitu kelompok "Zona Cekungan Kendenglembu” dan "Zona Pantai”. Namun, kedua kelompok zona situs tersebut dihubungkan dengan sebuah sungai yang cukup besar, yaitu Sungai Kali Baru yang berhulu di Gunung Raung (3332 m dpl) dan bermuara di pantai selatan Jawa di Samudera Hindia.

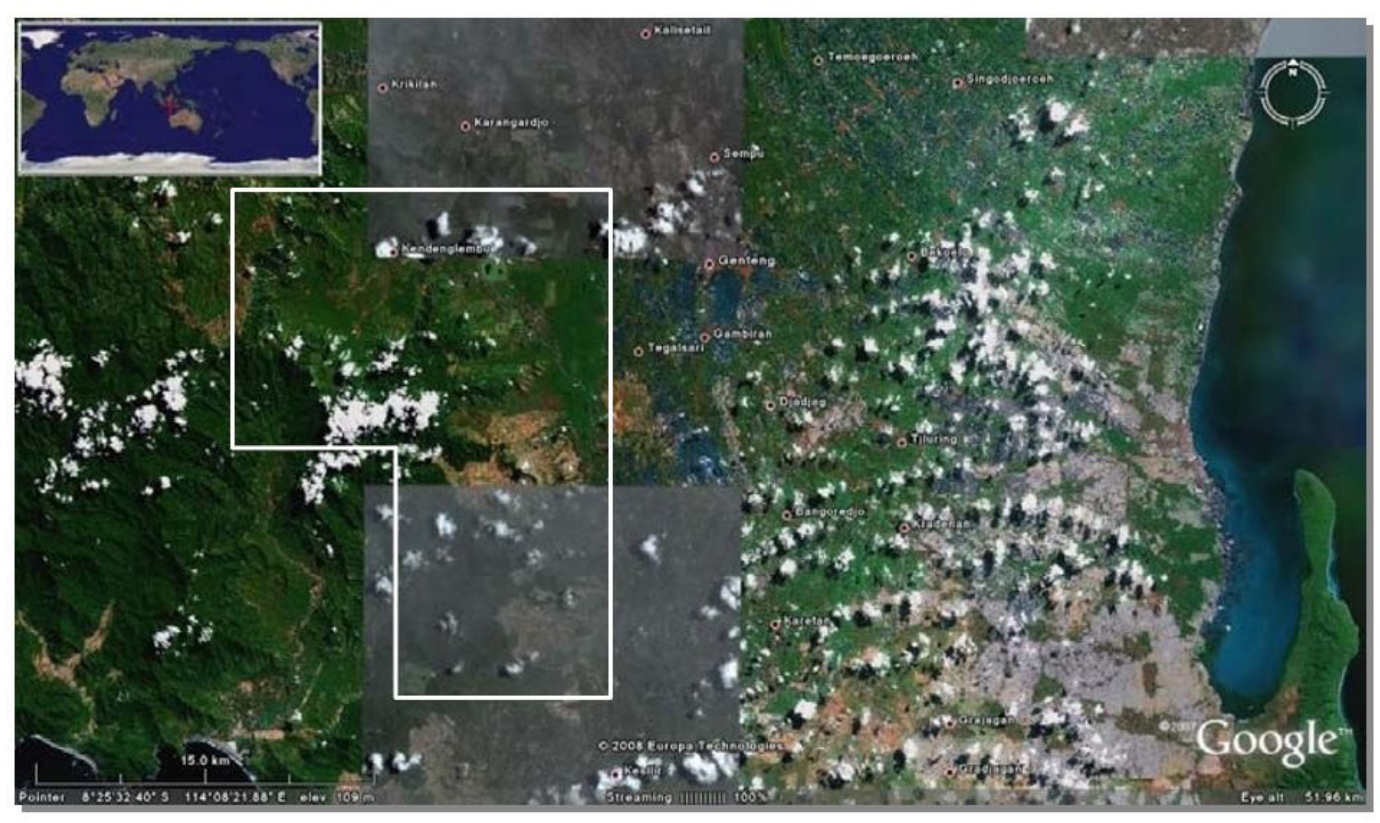

Peta 1. Sebaran situs megalithikum di sepanjang Sungai Kalibaru

Zona Cekungan Kendenglembu dibatasi oleh bentang alam pegunungan yang mengelilinginya, antara lain; Bukit Panggungrejo, Bukit Wilas, Bukit Margosugih, Bukit Carangan, Bukit Krigi, Bukit Kendit, Gunung Asri, Gunung Malaka, Gunung Sumberpacet, Gunung Nongkojajar, Gunung Lembu. Situs-situs yang termasuk dalam kelompok "Zona Cekungan Kendenglembu” adalah: Kendenglembu, Panuwunmukti, Kampung Anyar, Treblasala-Rejosari 1 (Kalitajem), Pagergunung, Sukobumi, Sukobumi Kampung. Sementara Situs-situs Zona Pantai secara administratif berada pada Desa Barurejo, Kecamatan Pesanggaran, Kabupaten Banyuwangi. Lokasi tersebut kemungkinan besar berada di sekitar pesisir pantai purba pada 4000 tahun yang lalu. Diperkirakan bahwa garis pantai purba pada masa neolitik berjarak kira-kira sekitar $8 \mathrm{Km}$ dari posisi 
garis pantai saat ini di Dusun Lampon, Desa Pesanggaran. Situs-situs yang termasuk dalam kelompok "Zona Pantai" adalah: Senepolor, Mulyosari, Seneposari, Seneposepi, Tanggul Arum, Manyarejo.

\section{Penjarahan Heritage di Malangsari}

Penjarahan warisan pra sejarah di Malangsari telah terjadi sejak pertengahan tahun 1990an. Dimulai dari penemuan-penemuan benda-benda purbakala berupa patung dan batu kenong (menurut istilah masyarakat setempat, karena bentuknya mirip dengan kenong) secara tak sengaja oleh masyarakat lokal, kemudian diikuti aktivitas pencarian oleh sekelompok individu dari wilayah sekitarnya. Menurut penuturan para pelaku, awal mulanya pencari harta karun itu adalah orang-orang dari Jember. Mereka berpindah ke Malangsari untuk menjadi pekerja di perkebunan kopi dan pada saat yang sama memiliki akses terhadap tempat-tempat yang menjadi lokasi utama situs pra sejarah. Sebagian besar situs ini berada di wilayah perkebunan kopi milik BUMN dan Perhutani.

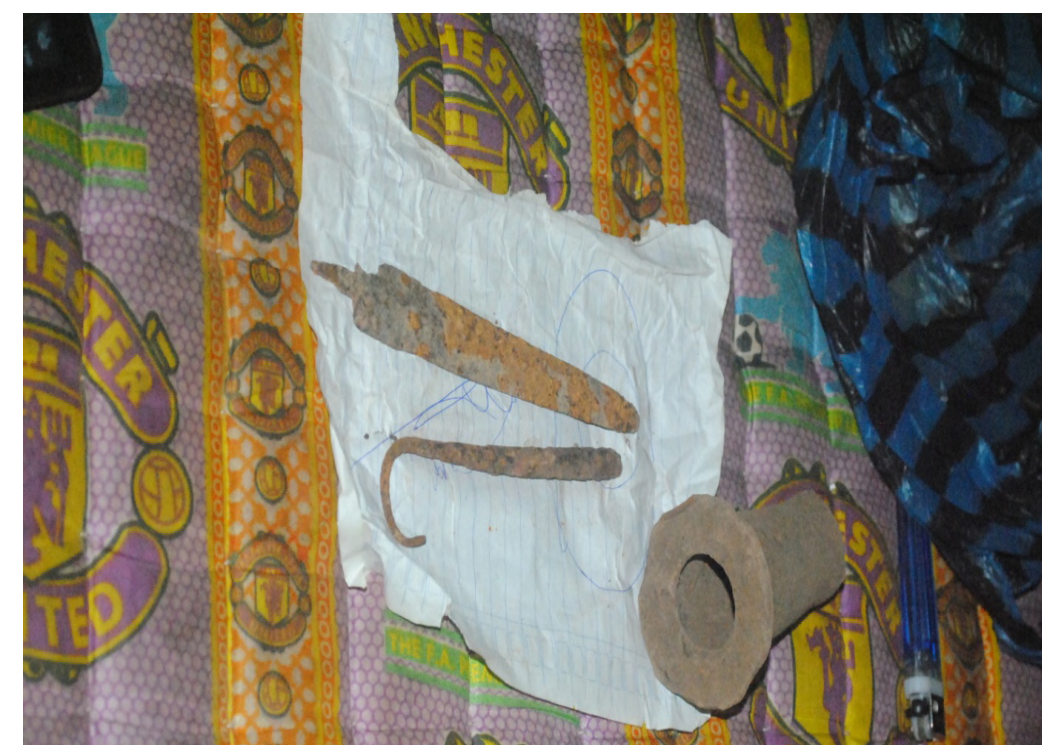

Foto 8. Beberapa hasil penggalian yang disimpan oleh penduduk.

Penjarahan dilakukan oleh para pekerja di perkebunan kopi, tetapi sebagian kecil lain juga melibatkan para pengawas perkebunan. Jika para pekerja kebun itu terlibat dalam penjarahan karena ingin menambah penghasilan, keterlibatan para pengawas perkebunan memiliki motif yang berlainan. Ada yang hanya ingin tahu, tetapi ada juga yang memiliki motif mencari keuntungan. Namun mereka ini bukan penjarah yang intens. Penjarah bisa bekerja secara sendiri tetapi juga bisa berkelompok. Penjarahan dilakukan umumnya di malam hari. Namun di beberapa tempat yang terisolir dari para penajaga kebun, penjarahan juga dilakukan pada siang hari. Penggalian kuburan yang dalamnya antara $70 \mathrm{~cm}$ hingga $200 \mathrm{~cm}$, memerlukan energi yang besar, apalagi jika dilakukan di malam hari. Menurut kesaksian para penjarah, penggalian umumnya dilakukan di musim hujan, karena tanah menjadi gembur sehingga mudah dicangkul dan ditusuk dengan deteksi batu kubur. 

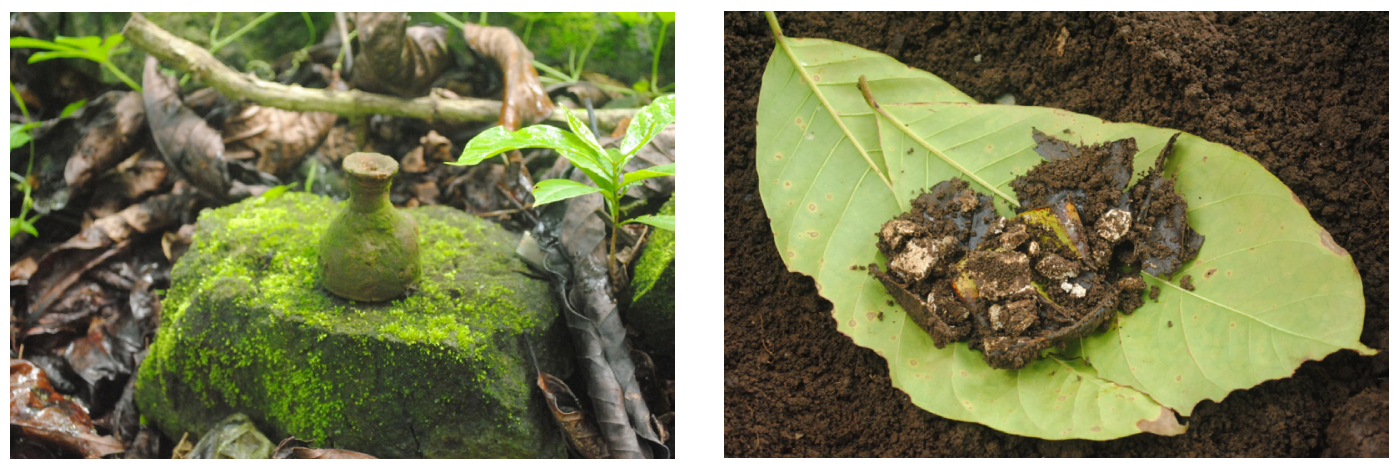

Foto 9 dan 10. Sisa penggalian oleh para penjarah harta karun yang dianggap tidak laku dijual sehingga ditinggalkan di lokasi

Ada dua alat utama yang dibawa oleh para penjarah, yaitu berupa tongkat besi sepanjang kurang lebih 2 meter. Tongkat digunakan untuk menusuk tanah, mendeteksi keberadaan batu kubur yang ada di dalam tanah. Jika tusukan ke tanah terhenti pada kedalaman tertentu oleh benda keras, maka tongkat di tarik. Pada ujung tongkat akan terlihat serpihan batu menempel. Setelah itu penjarah bisa langsung menggali. Bisa juga penjarah hanya menandati lokasi tersebut dan menunggu kesempatan yang baik untuk menggali.

Barang-barang yang dicari di dalam kubur adalah benda-benda berharga terutama perhiasan emas. Perhiasan ini dapat berupa lempengan, cincin, atau tindik hidung. Barang lain berupa senjata, seperti keris atau pisau yang terbuat dari bahan logam atau perunggu. Sisanya yang jumlahnya sangat banyak berupa manik-manik berwarna-warni yang terbuat dari berbagai bahan, antara lain dari getah.

Pada awalnya penggalian bersifat acak. Setiap menemukan serpihan batu di ujung tongkat besi langsung digali. Namun seringkali cara seperti ini sering mengecewakan karena hanya ditemukan batu kubur tanpa barang berharga. Kubur sering hanya berisi manik-manik berbahan getah. Dari pengalaman ini maka para penjarah mulai menjalankan teknik lain yang melibatkan kemampuan atau teknik spiritual. Para penjarah melakukan deteksi di banyak tempat dengan tusukan tempat besi. Kemudian para penjarah akan mengambil sejimpit tanah dari tempat yang diduga ada batu kuburnya. Tanah itu dimasukkan ke dalam kantong plastik dan dibawa pulang. Di rumah dipersiapkan gula dan api. Pada petang atau malam hari tanah dan gula itu dibakar.

Selanjutnya penjarah akan menunggu di dalam rumah, menghadap ke pintu rumah yang dibiarkan terbuka. Jika di depan rumah muncul sosok roh, maka kemungkinan di dalam kuburan itu ada benda-benda bekal kuburnya. Namun para penjarah juga memperhatikan pakaian atau perhiasan yang dikenakan oleh sosok roh yang datang. Jika mereka berpakaian bagus, maka kemungkinan besar di kuburan itu terdapat benda berharga dan jika tidak berpakaian atau berpakaian jelek, maka kemungkinan bekal kuburya tidak berharga. Para penjarah hanya akan melakukan penggalian jika roh yang datang berpakaian bagus dan mengenakan perhiasan berharga. Mereka meyakini bahwa roh yang datang itu adalah roh orang yang tanah kuburnya telah mereka bawa pulang itu. Ia bisa sosok dewasa laki-laki maupun perempuan dan anak-anak. Jika rohnya anak-anak biasanya ditemani oleh orang tuanya. 
Teknik lain yang digunakan penduduk untuk mendeteksi adanya benda berharga dalam kubur adalah dengan cara melakukan deteksi atau penusukan tanah menjelang petang hari, kemudian menungguinya hingga malam hari. Biasanya memasuki petang hari di atas tanah yang diduga ada batu kuburnya itu akan muncul roh yang duduk atau berdiri di sana. Para penjarah kemudian akan meninggalkan tempat jika roh sudah muncul. Mereka akan kembali ke lokasi kubur itu di hari lain untuk menggali jika mereka melihat sosok roh mengenakan perhiasan.

Dengan pengalaman yang semakin bertamabah itu, areal operasi para penjarah menjadi semakin luas. Mereka berpedoman bahwa umumnya kuburan pra sejarah berada sekitar gundukan bukit di sebelah kanan dan kiri sungai. Mereka mencari bekal kubur di bagian atas dari bukit karena benda berharga berupa emas lebih banyak terdapat dalam kuburan-kuburan yang terletak di bagian atas dari bukit itu. Kuburan yang berada di bagian bawah bukit umumnya memiliki bekal kubur berupa manik-manik.

Hasil dari penjarahan dijual ke penadah. Barang yang berupa emas dijual kepada toko-toko emas. Para pemilik toko emas sudah terbiasa dengan barang tadahan dari bekal kubur ini. Mereka memperlakukan emas dari bekal kubur sebagai emas dengan kualitas tinggi dan dihargai tinggi sesuai beratnya. Barang-barang lain baik berupa patung dan manik-manik juga ada penadahnya sendiri. Oleh para penadah, barangbarang itu kemudian dijual kepada pedagang barang antik atau pemilik galeri. Umumnya mereka berasal dari Bali.

Salah seorang pelaku penjarahan menceritakan bahwa ia mulai ikut menjarah karena diajak oleh seorang teman yang sudah sejak lama melakukannya. Ia menjadi semakin gemar melakukan penjarahan sejak merasakan bahwa benda-benda itu cukup menghasilkan uang. Ia menjarah bersama-sama secara berkelompok maupun sendiri. Ia cukup selektif dalam memilih kuburan untuk digali karena fokus pada pencarian benda berharga khususnya emas dan tidak mengambil bekal kubur selain emas. Informan ini mengatakan, sebisa mungkin tidak merusak posisi batu kubur yang telah ia bongkar. Ia menimbun kembali kuburan yang digalinya. Kehati-hatian ini dilakukan, katanya, karena mempertimbangkan pengalaman mistis yang menimpa salah satu temannya.

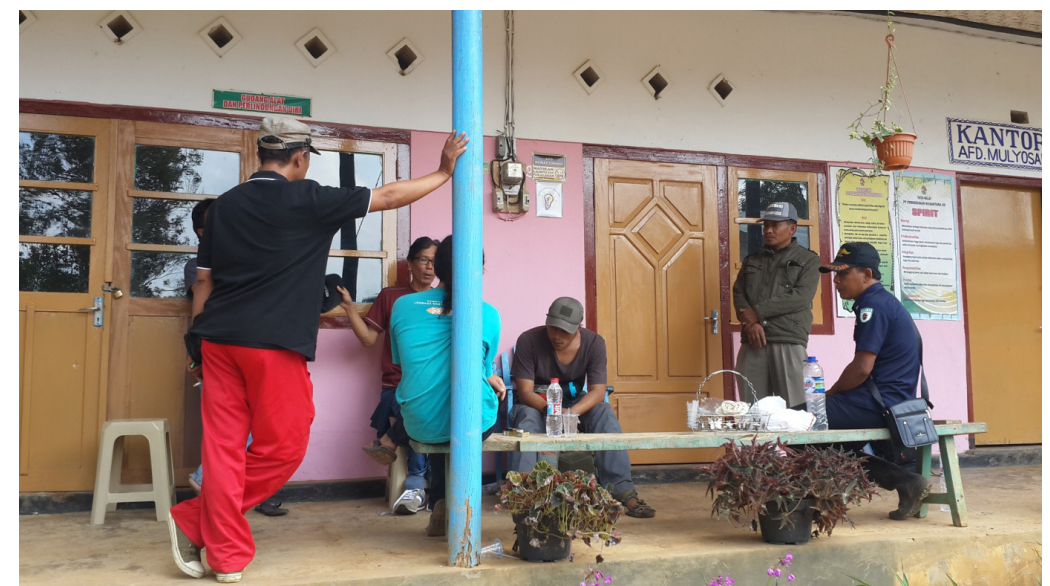

Foto 11. Diskusi dengan sejumlah warga dan para pegawai perkebunan, mereka diharapkan dapat menjadi pang pintu pertama untuk mencegah meluasnya penjarahan. 
Informan menceritakan bahwa, salah seorang temannya kehilangan pendengaran setelah merusak sebuah kuburan yang ia gali. Ia membongkar sisa-sisa tulang yang ada di sebuah liang kubur dan tidak mengembalikannya ke posisi semula. Ia juga mengambil sebuah pedang bekal kubur, yang kemudian dijual kepada seorang kyai di Madura. Informan menceritakan bahwa seorang dukun mengatakan bahwa temannya bisa sembuh jika mengembalikan pedang yang telah diambilnya dari liang kubur. Namun hal itu sulit dipenuhi karena alamat pembeli pedang tidak diketahui dan harga tebus-kembali pedang dipastikan sangat tinggi.

Mengikuti jejak para penjarah benda prasejarah ini tampak bahwa wilayah operasi mereka sangat luas. Dari massifnya praktek penjarahan ini dapat diperkirakan ribuan kuburan telah rusak. Meskipun demikian, para penjarah menyatakan bahwa masih ada ribuan kuburan yang belum mereka sentuh.

\section{Rekomendasi Penanganan}

Melihat permasalahan yang kompleks tentang keberadaan situs makam purba di Mulyosari, penanganan yang dapat dilakukan perlu melibatkan sejumlah pihak sekaligus. Maka koordinasi menjadi langkah sangat strategis yang mendesak. Koordinasi perlu dilakukan, pertama, antara pemilik/pengelola lahan perkebunan (yaitu PTPN XII dan Perhutani) dengan pemerintah daerah maupun pemerintah pusat. Kedua, koordinasi antara arkeolog dan sejarawan. Ketiga, koordinasi antara dinas pariwisata dan masyarakat setempat serta kelompok-kelompok pecinta warisan budaya. Berikut beberapa butir rekomendasi untuk penanganan dan pelestarian:

\section{Koordinasi dengan pemilik/pengelola laban dan pemerintab}

Mengingat situs makam purba tersebar di wilayah lahan perkebunan kopi yang dimiliki oleh dua instansi yang berbeda, yaitu PTPN XII dan Perhutani, maka upaya penanganan dan pelestarian situs memerlukan koordinasi dan komunikasi yang baik dengan mereka. Sangat penting untuk menyemaikan kesadaran di antara para pejabat dan pekerja dari kedua instansi tersebut tentang pentingnya melestarikan keberadaan situs makam purba, sambil tetap menekankan status dan fungsi utama lahan sebagai kebun produksi yang juga harus dijaga dari dampak-dampak buruk akibat pelestarian makam. Selain itu perlu penjelasan yang komprehensif mengenai potensi dan manfaat ekonomi yang dapat dinikmati oleh kedua instansi dari pengelolaan makam tersebut. Koordinasi dan komunikasi yang baik dengan pihak pemilik lahan tempat makam akan memudahkan akses para peneliti maupun pihak-pihak lain yang terkait ke area situs.

Juga diperlukan koordinasi dan perencanaan antara para pihak pemilik lahan dengan pemerintah, khususnya dinas Pekerjaan Umum, dalam hal penyediaan infrastruktur fisik penunjang, terutama jalan akses ke wilayah perkebunan dan situs makam serta lampu-lampu penerangan jalan.

\section{Koordinasi arkeolog dan sejarawan}

Diperlukan koordinasi dan sinergi antara arkeolog, sejarawan dan pemerintah untuk mengelola dan mengolah situs makam purba dari sisi substansi kearkeologian dan kesejarahan. Selama ini belum terlihat keterlibatan sinergis antara para ahli arkeologi dan 
sejarah. Pelestarian situs makam purba menuntut gerak bersama pihak-pihak tersebut. Dalam hal ini, peran Balai Arkeologi dan para arkeolog kampus sangat dibutuhkan untuk meneliti situs makam purba secara detil dan menyeluruh sehingga diperoleh informasi ilmiah yang akurat tentang keberadaan situs makam purba tersebut. Kerjakerja ilmiah dari para peneliti dapat menjadi data dasar bagi Tim Ahli Cagar Budaya untuk dilakukannya penetapan wilayah ini baik sebagai kawasan maupun situs cagar budaya. Dengan demikian, perlindungan akan dapat diberikan secara lebih optimal. Para sejarawan baik dari kampus maupun khususnya para penggiat sejarah lokal dapat menyajikan paparan ilmiah menyangkut aspek historis, misalnya asal-usul wilayah/ lahan tempat makam purba tersebut terletak, sejarah sosial ekonomi yang melingkupi terbentuknya wilayah perkebunan tersebut, dan apakah di masa lalu dalam proses terbentuknya wilayah perkebunan sudah ada pengetahuan/kesadaran tentang keberadaan situs makam purba itu.

\section{Koordinasi dinas pariwisata dan masyarakat setempat}

Untuk memudahkan keterlibatan berbagai pihak secara luas dalam pengelolaan dan pelestarian situs makam purba, maka nilai dan manfaat ekonomi dari upaya-upaya pelestariannya harus dapat dinikmati hasilnya secara ekonomi secara langsung oleh masyarakat. Dalam hal ini diperlukan koordinasi yang baik dengan dinas pariwisata setempat agar disusun program-program paket wisata yang memasukkan situs makam purba sebagai salah satu daerah kunjungan.

Diperlukan pendampingan terhadap masyarakat di sekitar lokasi situs makam purba agar mereka tidak merusak lagi situs makam purba dengan melakukan penggalian liar. Selain itu diperlukan juga pendampingan agar masyarakat dapat siap menjadi peserta program pariwisata misalnya dengan menjadi pemandu lokal (dengan pemahaman ilmiah yang memadai tentang situs makam purba melalui pelatihan terlebih dahulu), atau dengan terlibat melalui cara lain (penyedia tempat penginapan, pedagang makanan/ minuman maupun pernak-pernik lain terkait situs makam purba).

\section{Penutup}

Situs megalitikum di Banyuwangi menyimpan potensi data sejarah untuk mengungkap keberadaan dan asal-usul masyarakat manusia di Jawa pada masa lalu. Sebagaimana dikatakan ahli arkeologi Ron Hatley, ada pengaruh kuat peradaban masyarakat Pasifik dalam pembentukan awal peradaban di Jawa sebelum kedatangan pengaruh HinduBuddha dari India. Pernyataan Hatley memberikan gambaran tentang potensi pluralitas historiografi atas asal-usul purba manusia Jawa yang sangat mungkin terkandung di dalam hamparan beratus hektar makam purba di wilayah Banyuwangi.

Untuk melindungi dan sekaligus mengolah keberadaan makam purba di Banyuwangi sebagai landasan pengembangan berbagai sektor, beberapa kemungkinan langkah pengelolaan situs purba dapat ditempuh, di antaranya:

Penetapan wilayah ini sebagai cagar budaya sehingga memiliki perlindungannya kekuatan hukum yang kuat. Penetapan dapat dilakukan melalui rekomendasi Tim Ahli Cagar Budaya di Banyuwangi. 
- Pemetaan luasan dan sebaran area makam

- Klasifikasi makam berdasarkan cerita/pengetahuan warga setempat

- Penggalian dan pendataan arkeologis sampel makam

- Penjelasan arkeologis dan identifikasi makam

- Penyusunan penjelasan sejarah tentang makam

- Penentuan satu atau dua sampel makam yang telah digali untuk dijadikan museum alam terbuka yang dapat dikunjungi khalayak luas

- Pembuatan peta wisata situs makam purba berdasarkan kajian arkeologis dan historis. Luasan peta wisata tidak harus sama dengan sebaran keseluruhan area makam.

- Pendampingan terhadap program-program pariwisata pemerintah.

- Pendampingan terhadap masyarakat setempat.

- Penyusunan program-program lanjutan pengelolaan dan pelestarian makam melibatkan semua pihak terkait (pemerintah, pemilik lahan, masyarakat setempat, arkeolog, sejarawan, kampus, dan lain-lain). 